\title{
Factors Influencing Nurses' Compliance Level in the Application of Hand Hygiene in Inpatient Wards of Muntilan General Hospital
}

\author{
Andika Dwi Rianita*, Dyah Suryani* \\ *Correspondence Author: dyahsuryani.ds@gmail.com \\ *Universitas Ahmad Dahlan, Jl. Kapas No.9, Semaki, Kec. Umbulharjo, Kota Yogyakarta, Indonesia
}

\section{N D E X I N G}

Keywords:

Motivation;

Attitude;

Work Period;

Compliance;

Hand Hygiene;

Kata kunci:

Motivasi;

Sikap;

Masa kerja;

Kepatuhan;

Hand Hygiene;

\begin{abstract}
A B S T R AC T
Infectious diseases are still the leading cause of morbidity and mortality in the world. One of the infections was nosocomial infection.Nurses have appreciable influence regarding nosocomial infection incident, because nurses have a great deal of interaction with patient during 24 hours. The prevention of nosocomial infection can be conducted by nurse is with hand hygiene practice.The purpose of this research is to know factors influencing nurses' compliance level in application of hand hygiene at in inpatient ward of Muntilan General Hospital.This was a quantitative research with research design cross-sectional. Sampling technique used was the Proportionate Stratified Random Sampling with the number of respondents was 54 nurses. The instrument of the research applied a questionnaire and checklist. Analyses of data used were Chi-Square test. This research indicated there was a correlation between motivation with compliance level of nurses in application of hand hygiene (p-value 0.000).There was a correlation between attitudes with compliance level of nurses in application of hand hygiene (p-value 0.000).There was no correlation between work period with compliance level of nurses in application of hand hygiene ( $p$-value 0.459). There was a correlation between motivation and attitude with compliance level and no correlation between work period with compliance level of nurses in application of hand hygiene practice in of Muntilan General Hospital.
\end{abstract}

Penyakit infeksi merupakan penyebab utama tingginya angka kesakitan dan kematian di dunia. Salah satunya adalah Infeksi Nosokomial. Perawat memiliki pengaruh yang cukup besar terhadap terjadinya Infeksi Nosokomial, karena perawat paling banyak melakukan kontak dan berinteraksi secara langsung dengan pasien selama 24 jam. Upaya pencegahan Infeksi Nosokomial yang dapat dilakukan perawat adalah dengan menerapkan hand hygiene. Tujuan penelitian ini untuk mengetahui faktor-faktor yang berhubungan dengan tingkat kepatuhan perawat dalam penerapan hand hygiene di Bangsal Rawat Inap RSUD Muntilan. Jenis penelitian ini adalah penelitian kuantitatif dengan rancangan penelitian yang digunakan adalah cross-sectional. Teknik pengambilan sampel menggunakan Proportionate Stratified Random Sampling dengan jumlah responden 54 perawat. Instrumen penelitian menggunakan kuesioner dan checklist. Analisis data menggunakan uji ChiSquare. Penelitian ini menunjukkan ada hubungan antara motivasi dengan tingkat kepatuhan hand hygiene perawat (p-value 0,000). Ada hubungan antara sikap dengan tingkat kepatuhan hand hygiene perawat (p-value 0,000). Tidak ada hubungan antara masa kerja dengan tingkat kepatuhan hand hygiene perawat (p-value 0,459). Ada hubungan antara motivasi dan sikap dengan tingkat kepatuhan perawat dalam penerapan hand hygiene serta tidak ada hubungan antara masa kerja dengan tingkat kepatuhan perawat dalam penerapan hand hygiene di Bangsal Rawat Inap RSUD Muntilan.

(C) 2019 JMMR. All rights reserved

\section{INTRODUCTION}

Infectious diseases are still the leading cause of morbidity and mortality in the world. One of the infections was Nosocomial infection. This infection causes 1.4 million of mortality every day in the whole world..$^{-}$Hospitals are required to be able to provide quality services in accordance with predetermined standards. Other health care facilities are faced with the risk of infection, either because of treatment or coming to visit hospitals. ${ }^{2}$

Nosocomial infection is currently one of the causes of increased morbidity and mortality in hospitals, so that it can lead to a new health problem in developing and advanced countries. Nosocomial infections currently remain a problem that is quite attention-grabbing. The incidence of Nosocomial infection is different from one hospital to 
another. The incidence of Nosocomial Infection is recorded in various countries around $3.3 \%-9.2 \%$, meaning that a percentage of patients treated are infected with Nosocomial Infection and it can occur acutely or chronically.

Infection that is not only found in hospitals, the term Nosocomial Infection is expanded with the terms Healthcare-Associated Infections (HAIs). The prevalence of Healthcare-Associated Infections (HAIs) is estimated at 1.4 million worldwide. This causes 50.000 deaths and 2 million morbidities caused by Healthcare-Associated Infections (HAIs) in advanced countries each year, and results in additional 14 days of being hospitalized and additional annual health costs.--

Nurses have an appreciable influence on the occurrence of Nosocomial Infection, because nurses are health workers who have a great deal of interaction with patient during 24 hours. The prevention of Nosocomial Infection that can be done by nurses is by increasing the ability to apply standard precaution whose main component is one of the most effective methods to prevent transmission of pathogens in hospitals. Efforts to implement standard precautions can be done by doing hand hygiene which is through hand hygiene practices. ${ }^{-}$Hand hygiene is important in prevention because it is more effective and low cost. Besides, the impact will be decresead on Healthcare-Associated Infections (HAIs) is $50 \%$ by implementing hand hygiene. ${ }^{6}$

Based on the findings of a preliminary study at Muntilan General Hospital, the percentage of the average incidence of Nosocomial Infection in inpatient wards in the fourth quarter of 2017 was $0.9 \%$. Phlebitis is a Nosocomial Infection with the highest incidence in the fourth quarter, which is $9.4 /$ mile or $0.94 \%$ and exceeds the target of $1 /$ mile or $0.1 \%$.

The average percentage of nurse compliance in the application of hand hygiene in the fourth quarter of 2017 was $55 \%$, which showed that the compliance of hand hygiene nurses still had not reached the compliance standard for $75 \%$ hand hygiene implementation at Muntilan General Hospital guided by the World Health Organization (WHO) and the Centers for Disease Control and Prevention (CDC). Based on the results of interviews with a Supervisor of Infection Prevention and Control at Muntilan General Hospital, information was obtained that nurses' motivation to implement hand hygiene was still poor. Nurses had already known about 5 moments of hand hygiene and 6step hand hygiene procedures according to the standards of the World Health Organization (WHO) and can apply them well, but the willingness of nurses to implement hand hygiene is still very poor. This study aims to determine the factors associated with the level of nurse compliance in the application of hand hygiene in the inpatient ward of Muntilan General Hospital.

\section{RESEARCH METHOD}

This is quantitative research with analytical observational research methods. The study design used was cross-sectional. The variables in this study were motivation, attitudes, work period and the level of compliance of nurses' hand hygiene. The number of respondents was 54 nurses, the sampling technique used was the Proportionate Stratified Random Sampling, which is a technique that is used if the population has members or elements that are not homogeneous and have proportional strata.- The research instrument used a questionnaire and checklist. Data analysis using univariate analysis and bivariate analysis with ChiSquare test.

\section{RESULT AND DISCUSSION}

\section{Respondent Characteristic}

The number of respondents in this study was 54 nurses. The general characteristics of nurses in the Flamboyan Ward, Dahlia, Anggrek, Mawar, Seruni, Aster, Menur, Gladiolus in Muntilan General Hospital are presented in the table of characteristics of respondents below:

Table 1. Characteristics of Respondents in the Inpatient Ward of Muntilan General Hospital

\begin{tabular}{llcc}
\hline No. & \multicolumn{1}{c}{$\begin{array}{c}\text { Respondent } \\
\text { Characteristics }\end{array}$} & n & \% \\
\hline $1 . \quad$ Age (Year) & 3 & 5.6 \\
& $17-25$ & 27 & 50 \\
& $26-35$ & 20 & 37 \\
& $36-45$ & 4 & 7.4 \\
& $46-55$ & & \\
2. & Sex & 7 & 13 \\
& Male & 47 & 87 \\
Female & & \\
Education Level & 1 & 1.9 \\
& SPK & 41 & 75.9 \\
D3 & 2 & 3.7 \\
D4 & 10 & 18.5 \\
Degree & & \\
Basic Training of Infection & & \\
Prevention and Control & 13 & 24.1 \\
No & 41 & 75.9 \\
\hline
\end{tabular}

In table 1 , it can be seen that the age of nurses in the Inpatient Ward of Muntilan General Hospital with the 
highest number is based on age categorization according to the Republic of Indonesia Ministry of Health, which is in the age range $26-35$ years with 27 nurses $(50 \%)$ and at least $17-25$ years with 3 nurses (5.6\%). Based on the research data obtained, the minimum age of nurses is 23 years old and the maximum age of nurses is 50 years. The male nurses were 7 nurses (13\%) and female nurses were 47 nurses $(87 \%)$

Based on table 1, it can be seen that more nurses are educated D3 with a total of 41 nurses (75.9\%), Degree are 10 nurses (18.5\%), and the least nurses are SPK-educated which is only 1 nurse (1.9\%). Most nurses have a high level of education in the Inpatient Ward of Muntilan General Hospital. Nurses who had never participated in Basic Training of Infection Prevention and Control were 13 nurses (24.1\%) and nurses who had attended Basic Training of Infection Prevention and Control were 41 nurses (75.9\%). Most nurses have participated in the Training of Infection Prevention and Control was held at Muntilan General Hospital .

\section{Result of Univariate Analysis}

Based on the results of research obtained in the Flamboyan Ward, Dahlia, Anggrek, Mawar, Seruni, Aster, Menur, Gladiolus at the Muntilan General Hospital, the results of each variable motivation, attitudes, work period and compliance level of nurses in the application of hand hygiene based on the number and percentage can be seen in the table 2 .

Based on table 2, it can be seen that nurses who have poor motivation were 30 nurses $(55.6 \%)$, while nurses who have good motivation were 24 nurses (44.4\%). Nurses who have bad attitudes are 30 nurses (55.6\%), while nurses who have good attitudes are 24 nurses $(44.4 \%)$. Nurses with a short work period were 4 nurses $(7.4 \%)$ with a working period of $\leq 3$ years, while nurses with a long work period were 50 nurses $(92.6 \%)$ with a working period of $>3$ years. Nurses who had a poor level of hand hygiene were 32 nurses (59.3\%). However, nurses who had good levels of hand hygiene compliance were 22 nurses $(40.7 \%)$.

Based on table 2, it can be seen that nurses who have poor motivation were 30 nurses $(55.6 \%)$, while nurses who have good motivation were 24 nurses (44.4\%). Nurses who have bad attitudes are 30 nurses $(55.6 \%)$, while nurses who have good attitudes are 24 nurses (44.4\%). Nurses with a short work period were 4 nurses $(7.4 \%)$ with a working period of $\leqslant 3$ years, while nurses with a long work period were 50 nurses $(92.6 \%)$ with a working period of $>3$ years.
Table 2. Distribution of Frequency of Motivation, Attitude, Work Period, and Nurse Compliance Level in Hand Hygiene Implementation at Muntilan General Hospital

\begin{tabular}{llcc}
\hline No. & Variable & n & \% \\
\hline 1. & Motivation & & \\
& Poor & 30 & 55.6 \\
& Good & 24 & 44.4 \\
2. & Attitude & & \\
& Bad & 30 & 55.6 \\
& Good & 24 & 44.4 \\
3. & Work Period & 4 & \\
& Short & 7.4 \\
& Long & 50 & 92.6 \\
Compliance Level of & & \\
& Hand Hygiene & & \\
Poor & 32 & 59.3 \\
Good & 22 & 40.7 \\
\hline
\end{tabular}

Nurses who had a poor level of hand hygiene were 32 nurses $(59.3 \%)$. However, nurses who had good levels of hand hygiene compliance were 22 nurses (40.7\%).

\section{Relationship between Motivation and Nurse's Hand Hygiene Compliance Level}

The results of the statistical analysis with Chi-Square test between motivation and the level of hand hygiene compliance in nurses in the Inpatient Ward of Muntilan General Hospital can be seen in table 3. Based on table 3, it can be seen that nurses with poor motivation categories have a poor level of hand hygiene compliance were 26 nurses with a percentage of $48.15 \%$, while nurses with good motivation categories have good levels of hand hygiene were 18 nurses with percentage of $33.33 \%$. Based on the results of bivariate analysis using the chi square test obtained the value of $p$ value of $0.000(p<0.05)$, then $\mathrm{Ha}$ is accepted. This showed that there was a significant relationship between nurses' motivation and the level of nurse compliance in the application of hand hygiene in the Inpatient Ward of Muntilan General Hospital .

The value of Prevalence Ratio (RP) showed 3.467 (RP> 1) and the value of $95 \%$ Confident Interval (CI) was 1.709 -7.030 which means that $\mathrm{CI}$ does not cover number 1 . So that, poor motivation category is a risk factor which means nurse with low motivation has a risk of 3.467 times greater for not performing good hand hygiene compliance compared to nurses with good motivation. 
Table 3. Relationship between Motivation and the Level of Compliance of Hand Hygiene of Nurses in the Inpatient Ward of Muntilan General Hospital

\begin{tabular}{|c|c|c|c|c|c|c|c|}
\hline \multirow{3}{*}{ Motivation } & \multicolumn{5}{|c|}{ Compliance Level } & \multirow{2}{*}{\multicolumn{2}{|c|}{$\mathbf{R P}$}} \\
\hline & \multicolumn{2}{|c|}{ Poor } & \multicolumn{2}{|c|}{ Good } & \multirow[t]{2}{*}{ P Value } & & \\
\hline & $\mathbf{n}$ & $\%$ & $\mathbf{n}$ & $\%$ & & $(95 \%$ & CI) \\
\hline Poor & 26 & 48.15 & 4 & 7.41 & \multicolumn{3}{|c|}{3,467} \\
\hline Good & 6 & 11.11 & 18 & 33.33 & \multirow[t]{2}{*}{0.000} & \multicolumn{2}{|c|}{ (1.709 - } \\
\hline Total & 32 & 59.3 & 22 & 40.7 & & \multicolumn{2}{|c|}{ 7.030) } \\
\hline
\end{tabular}

Infection or what is now referred to as a related infection with health services or Healthcare Associated Infections (HAIs) is an important problem in hospitals. ${ }^{-}$The results of the research conducted are in line with previous research which showed that there was a significant relationship between nurses' motivation and hand washing in the Seruni and Teratai ward in General Hospital of Dr. M. Yunus Bengkulu with $\mathrm{p}$ value of $0.030 .{ }^{-}$

Based on the results of the study using a motivation questionnaire on 54 respondents, the results showed that there were still many respondents who had poor motivation in implementing hand hygiene. There were 30 nurses from 54 respondents with a percentage of $55.6 \%$ getting a motivation score $<59$ (Table 2). This study is in line with research conducted that showed that nurses who have poor motivation of $72.1 \%$, the percentage of nurses with poor motivation is greater when compared to the nurses with high motivation..$^{10}$ Theory states that motivation is important to encourage people to work because motivation is an energy that encourages them to rise to the task of achieving the stated goals. Achievement of goals is influenced by the high and low motivation of work which will ultimately affect the results of the work done."

Motivation of nurses in Muntilan General Hospital can be derived from internal nurses obtained because of the encouragement or willingness in nurses which is the encouragement to improve compliance with hand hygiene at five moments for hand hygiene and hand hygiene steps are carried out according to the procedure. External motivation of nurses in the Inpatient Ward of Muntilan General Hospital can be obtained from the Chief in each inpatient ward. Leadership factors are very influential in giving encouragement to nurses to properly carry out hand hygiene according to procedures to prevent Nosocomial Infection in hospitals. Based on the results of the study using a motivational questionnaire, the majority of respondents in Flamboyan Ward and the Dahlia Ward mostly had high hand hygiene motivation compared to respondents in other wards. This is because the leadership of the Chief in the Flamboyan Ward and Dahlia has been good at providing motivation, direction, and guidance to work together on the team.

In order to get what they want, it is not easy to obtain without maximum effort. In fulfilling the needs, people will behave according to their motivation and what underlies their behaviour. So that it can be said that there is strength in a person. Motivation that gives a person's strength to behave can come from internal or external. Motivation theory provides an explanation of one's needs and desires and shows the direction of action. $\frac{12}{}$

Positive increase in nurse motivation can be conducted through the provision of rewards to nurses who have good compliance with the implementation of hand hygiene according to standards. Negative motivation increase of nurses can be conducted with the punishment given to nurses who are not obedient in carrying out hand hygiene which is through the presence of reprimands and sanctions so that nurses are more motivated to carry out hand hygiene because of the effect of fear of punishment given by their superior. This is supported by a theory that states that there is a positive motivation that always gives rewards to members who succeed in taking good actions and negative motivations that always give punishment or threats to members who in carrying out inappropriate actions. ${ }^{13}$

\section{Relationship between Attitudes and Nurses' Hand Hygiene Compliance Levels}

The results of statistical analysis with Chi-Square test between attitudes and levels of hand hygiene to nurses in the Inpatient Ward Muntilan Regional General Hospital can be seen in table 4 . 
Table 4. Relationship between Attitude and Level of Compliance with Hand Hygiene of Nurses in the Inpatient Ward of Muntilan General Hospital

\begin{tabular}{|c|c|c|c|c|c|c|c|c|}
\hline \multirow{3}{*}{ Attitude } & \multicolumn{5}{|c|}{ Compliance Level } & \multirow{3}{*}{$\begin{array}{r}\text { Total } \\
\quad \% \\
\end{array}$} & \multirow{3}{*}{$P$ Value } & \multirow{3}{*}{$\begin{array}{c}\text { RP } \\
95 \% \text { CI }\end{array}$} \\
\hline & Poor & & & & & & & \\
\hline & $\mathbf{n}$ & $\%$ & n & $\%$ & $\mathbf{n}$ & & & \\
\hline $\mathrm{Bad}$ & 25 & 46.29 & 5 & 9.26 & 30 & 55.6 & \multirow{3}{*}{0,000} & 2.857 \\
\hline Good & 7 & 12.96 & 17 & 31.48 & 24 & 44.4 & & $(1.501-$ \\
\hline Total & 32 & 59.3 & 22 & 40.7 & 54 & 100 & & $5.439)$ \\
\hline
\end{tabular}

Based on table 4, it can be seen that nurses with bad attitude have poor levels compliance of hand hygiene were 5 nurses with a percentage of $46.29 \%$, while nurses who have good attitude have good levels compliance of hand hygiene adherence were 17 nurses with percentage of $31.48 \%$. Based on the results of bivariate analysis using the chi square test obtained the value of $\mathrm{p}$ value of 0.000 ( $\mathrm{p}$ $<0.05$ ), then $\mathrm{Ha}$ is accepted. This shows that there is a significant relationship between the attitude of nurses and the level of nurse compliance in the application of hand hygiene in the Inpatient Ward of Muntilan Geneal Hospital.

The value of the Prevalence Ratio (RP) shows the number $2.857(\mathrm{RP}>1)$ and the value of $95 \%$ Confident Interval $(\mathrm{CI})$ is $1.501-5,439$ which means that $\mathrm{CI}$ does not cover the number 1 . Then, the category of bad attitude is a risk factor which means nurses with categories of bad attitude has a risk of 2.857 times greater for not performing good hand hygiene compliance compared to nurses who have a good attitude. The results of research conducted by researchers are in line with research that shows that there is a significant relationship between attitudes and compliance of nurse's inpatient ward in the implementation of hand hygiene at Anna Medika Hospital of Bekasi with a $\mathrm{p}$ value of $0.005 . \stackrel{14}{.}$

Based on the results of the study using attitude questionnaires on 54 respondents, the results showed that most respondents had a bad attitude in implementing hand hygiene which is 30 nurses from 54 respondents with a percentage of $55.6 \%$ getting attitude scores $<64$ (Table 2). This study is in line with research that shows that nurses who have a bad attitude is as $60.5 \%$, the percentage of nurses with a bad attitude is greater when compared with the attitude of a good nurse..$^{15}$ Based on observations conducted by researchers, it can be seen that when nurses contact with patients and before nurses perform the action of asepsis, there were still nurses who did not apply hand hygiene. In carrying out nursing care actions at the moment before contact with the patient and before the act of asepsis, nurses who wore PPE (Personal Protective Equipment) such as masks and medical gloves did not carry out hand hygiene. The nurse only carried out hand hygiene after taking nursing care measures by removing medical gloves and then washing hands with a handwash. When washing hands with a handwash, most nurses did not use tissue to cover the faucet after washing their hands. In addition, when nurses carry out hand hygiene with handrails or handwash, there are still nurses who did not remove the accessories in their hands such as rings and watches so that between fingers are not rubbed perfectly.

Based on the basic theory developed by Lawrence Green, behavioral factors are influenced by three factors include predisposing factors which is factors that facilitate or predispose to the occurrence of health behaviors, in this case the compliance of nurses' hand hygiene covering age, employment, education, knowledge and attitude. Enabling factors are factors that allow or facilitate behavior or actions, what is meant by enabling factors are tools and infrastructures as well as facilities for the occurrence of health behaviors that are manifested in the availability of good and standard hand hygiene facilities. Reinforcing Factors are factors that encourage or strengthen behavior. Sometimes even if someone knows and is able to behave well, they choose not to do it. It can be seen in nurses who were mostly aware of the benefits of hand hygiene for the prevention of Nosocomial Infection, but nurse compliance in the application of hand hygiene is still poor due to the attitude of nurses is still poor. ${ }^{-6}$ Attitudes are also influenced by culture. It has been known that culture has affected people's attitude towards various problems. The same as true with the attitude of nurses on the implementation of hand washing, if hand washing has been done as a work culture or pattern, then the implementation of hand washing will go well. ${ }^{17}$

Changes in attitudes can be influenced by information received and possessed by individuals as well as experiences held by individuals. The most important thing is the delivery of message that can motivate nurses so that it can shape the attitude of nurses to be better which enables nurses to behave well which is in terms of compliance with nurses' hand hygiene. In addition, the role of the Infection 
Control and Prevention officer is also needed to carry out more optimal supervision on the effectiveness of Nosocomial Infection prevention programs in hospitals to improve the compliance level in the application of hand hygiene.

\section{Relationship between Nurses' Period of Compliance with Hand Hygiene Compliance}

The results of statistical analysis with Chi-Square test between the work period with the level of compliance of hand hygiene to nurses in the Inpatient Ward of Muntilan General Hospital can be seen in table 5 .

Based on table 5, it can be seen that nurses with short work period categories have a poor level of hand hygiene of 3 nurses with a percentage of $5.55 \%$, while nurses with a long work period category who have good hand hygiene compliance levels of 21 nurses with a percentage of $38.88 \%$. Based on the results of bivariate analysis using the chi square test there were two cells $(50 \%)$ that have an expected count value of less than 5 , then the value of significance is seen in Fisher's exact test on the one-way hypothesis and $\mathrm{p}$ value is 0.459 ( $\mathrm{p}>0.05$ ), then $\mathrm{Ha}$ is rejected. This showed that there was no significant relationship between the work period of nurses and the level of nurse compliance in the implementation of hand hygiene in the Inpatient Ward of Muntilan General Hospital.

The value of the Prevalence Ratio (RP) showed the number $1.293(\mathrm{RP}>1)$ and the value of $95 \%$ Confident Interval (CI) is between $0.701-2.338$ which means that $\mathrm{CI}$ includes the number 1 . Then, the short work period category can not be said to be a risk factor.

The finding of the research conducted by researchers are in line with the research that showed that there was no significant relationship between the work period of nurses and the compliance of nurses' hand hygiene in the inpatient ward Rajawali general hospital of Dr. Kariadi Semarang with a value of $\mathrm{p}$ value $1.000(\mathrm{p}>0.05) . \stackrel{18}{ }$

Tabel 5. Relationship between Work Period and Hand Hygiene Compliance Level Nurse in the Inpatient Ward of Muntilan General Hospital

\begin{tabular}{|c|c|c|c|c|c|c|c|c|}
\hline \multirow{3}{*}{ Work Period } & \multicolumn{4}{|c|}{ Compliance Level } & \multirow{2}{*}{\multicolumn{2}{|c|}{ Total }} & \multirow{3}{*}{ PValue } & \multirow{3}{*}{$\begin{array}{r}\text { RP } \\
95 \% \text { CI }\end{array}$} \\
\hline & \multicolumn{2}{|c|}{ Fair } & \multicolumn{2}{|c|}{ Good } & & & & \\
\hline & $\mathbf{n}$ & $\%$ & $\mathbf{n}$ & $\%$ & $\mathbf{n}$ & $\%$ & & \\
\hline Short & 3 & 5.55 & 1 & 1.85 & 4 & 7,4 & & 1,293 \\
\hline Long & 29 & 53.70 & 21 & 38.88 & 50 & 92.6 & 0.459 & $(0.701-$ \\
\hline Total & 32 & 59.3 & 22 & 40.7 & 54 & 100 & & $2.387)$ \\
\hline
\end{tabular}

Usually the length of the work period is used to measure the loyalty of an employee, the longer the work period, the more loyal the employee is towards his company. It has been known how important the loyalty is, so that the company need to develop various rewarding policies by including the the length of the work period factor, for example awarding employees who have worked for many years, getting additional leave for employees who have worked for many years and others. ${ }^{19}$

In this study, most of the nurses had worked with a long work period at Muntilan general hospital. A total of 50 nurses with a percentage of $92.6 \%$ of the 54 respondents studied had a long work period. Based on this, it can be said that the loyalty of nurses working in Muntilan general hospital has shown high loyalty to hospitals, because more nurses with longer work period compared to shorter work period.
According to researchers the factors that influence uncorrelated relationship between the work period of nurses and the level of compliance with hand hygiene are that nurses with the short work period of work have fewer experiences and skills in carrying out their work and hand hygiene are still poor. In addition, nurses with a short work period also have not participated in the Basic Training of Infection Prevention and Control so that the knowledge and competence related to hand hygiene compliance to nurses is still poor. Meanwhile, for nurses with a long work period, motivation or encouragement coming from nurses to implement hand hygiene according to standards get decreased as the length of work period goes. Motivation affects the compliance of nurses to practice hand washing. High motivation of nurses will increase the compliance of nurses in practicing handwashing. Likewise on good nurses 'motivation, the practice of handwashing will also be well 
done and vice versa, insufficient motivation among nurses will result in poor hand washing practices..$^{20}$

The work period of nurses also influences a person's behavior. In accordance with the theory which states that the work period can affect one's work experience, so that the longer nurses have work period, the more experiences they will get. Workers with longer work period shows more work experiences compared to other colleagues. Workers with longer period have more experiences because they perform it repeatedly on a daily basis as a habit. The same as true with hand hygiene at five moments, nurses who have longer work period and make the hand hygiene as a very important thing, the nurse will get used to doing hand hygiene in five moments every day. .1

Nurses with long work period should provide positive work experience for their work, including nurses' compliance in implementing hand hygiene by standards. The behavior of junior nurses is influenced by the example shown by more senior nurses, meaning that if senior nurses show poor practice, negative socialization can occur..$^{22-23}$ There may also be other factors that can influence the compliance of nurses hand hygiene at Muntilan inpatient ward such as nurse skills, training, motivation, education, and nurses' attitudes. Increasing motivation and competence within the nurse is very necessary for a better hand hygiene compliance on nurses with the short work period and nurses with long work period.

\section{CONCLUSION}

Based on the results of research on factors related to the level of nurse compliance in the implementation of hand hygiene in the Inpatient ward of Muntilan General Hospital, it can be concluded that:

There is a relationship between motivation and attitudes with the level of nurse compliance in the application of hand hygiene in the inpatient ward at General Hospital. There is no relationship between work period and the level of nurse compliance in the application of hand hygiene in the inpatient ward General Hospital Muntilan.

From the results of the research that has been carried out, there are several recommendations that can be submitted to the hospital, should perform a briefing according to the shift work of nurse before nurses carry out duties that inlcude inserting material related to hand hygiene before nursing action Conduct a patient safety culture survey to measure nurses' knowledge regarding hand hygiene

\section{REFERENCE}

1. Septiari, B. (2012). Infeksi Nosokomial. Yogyakarta: Nuha Medika.

2. Kementerian Kesehatan Republik Indonesia. (2011). Pedoman Manajerial Pencegahan dan Pengendalian Infeksi Pelayanan Kesehatan. Jakarta: Departemen Kesehatan Republik Indonesia.

3. Darmadi, D. (2008). Infeksi Nosokomial Problematika dan Penanganannya. Jakarta: Salemba Medika.

4. World Health Organization (WHO). (2005). WHO Guidelines on Hand Hygiene in Health Care.

5. World Health Organization (WHO). (2009). WHO Guidelines on Hand Hygiene in Health Care: a Summary, First Global Patient Safety Challenge Clean Care is Safer Care.

6. Madrazo, M. (2009). Effectiveness of A Training Programme to Improve Hand Hygiene Compliance in Primary Healthcare. BMC Public Health, 9(469), 14712458.

7. Sugiyono. (2017). Metode Penelitian Kuantitatif, Kualitatif dan R\&D. Bandung: Alfabeta.

8. Departemen Kesehatan RI. (2009). Sistem Kesehatan Nasional. Jakarta.

9. Marlena, F. (2013). Motivasi Cuci Tangan Perawat di RSUD Dr. M. Yunus Bengkulu.Jurnal Mitra Raflesia. 5(1), 23-28.

10. Dewi, K. (2017). Faktor Determinan Kepatuhan Perawat dalam Melakukan Praktik Cuci Tangan di RSUD Ade Muhammad Djoen Sintang. Jurnal Kesehatan Masyarakat Khatulistiwa. 4(3), 233, 236.

11. Suyanto. (2009). Kepemimpinan dan Manajemen Keperawatan di Rumah Sakit. Yogyakarta: Mitra Cendekia.

12. Musta' an dan S. Haryanti. (2010). Hubungan antara Motivasi dengan Kinerja Perawat ditinjau dari Dokumentasi Asuhan Keperawatan di RS Paru Dr. Ario Wirawan Salatiga. Jurnal Ilmu Keperawatan Indonesia. 1(1), 1-12.

13. Notoatmodjo, S. (2012). Pengembangan Sumber Daya Manusia. Jakarta: Rineka Cipta.

14. Ratnasari, D., dan Dulakhir. (2016). Faktor-Faktor yang Berhubungan dengan Kepatuhan Perawat Ruang Rawat Inap dalam Pelaksanaan Hand Hygiene di Rumah Sakit Anna Medika Kota Bekasi Tahun 2016. Jurnal Ilmiah Kesehatan. 8(2), 32-36.

15. Sinaga, S. (2015). Kepatuhan Hand Hygiene di Rumah Sakit Misi Rangkasbitung. 
ejournal.stikesborromeus.ac.id/file/6-2.pdf, diambil pada tanggal 11 Juli 2018. Yogyakarta.

16. Notoatmodjo, S. (2014). Ilmu Perilaku Kesehatan. Jakarta: Rineka Cipta.

17. Rahmawati, R., dan Susanti, M. (2014). Pengetahuan dan Sikap Perawat Pencegahan Infeksi Nosokomial dalam Pelaksanaan Cuci Tangan Tahun 2014. Jurnal Fakultas Ilmu Kesehatan Universitas Gresik. 5(2), 190-195.

18. Amalia, R., Widagdo, L., dan Syamsulhuda. (2016). Faktor-Faktor yang Berhubungan dengan Tingkat Kepatuhan Tenaga Kesehatan Melakukan Cuci Tangan (Studi Kasus di Instalasi Rawat Inap Rajawali RSUP Dr. Kariadi Semarang. Jurnal Kesehatan Masyarakat. 4(3), 1086-1088.

19. Saragih, R., dan Rumapea, N. (2011). Hubungan Karakteristik Perawat dengan Tingkat Kepatuhan Perawat Melakukan Cuci Tangan di Rumah Sakit Columbia Asia Medan. Jurnal Ilmu Keperawatan. 3(1), 20-26

20. Zuidah. (2006). Pengaruh Strategi Universal Precaution Perawat Terhadap Tindakan Pasang Kateter Dalam Mencegah Nosokomial ISK di Rumah Sakit Haji Medan, Tesis, Medan. Program Pascasarjana-Universitas Sumatera Utara. https://repository.usu.ac.id/handle/123456789/6702.

21. Rivai,V., dan Mulyadi. (2010). Kepemimpinan dan Perilaku Organisasi. Edisi Ketiga. Jakarta: Raja Grafindo Persada

22. Huis A, Schoonhoven L, Grol R, Donders R, Hulscher M, van Achterberg T. (2013). Impact Of A Team And Leaders-Directed Strategy To Improve Nurses' Adherence To Hand Hygiene Guidelines: A Cluster Randomised Trial. Int J Nurs Stud. 50:464474.

23. Erasmus V, Brouwer W, van Beeck EF, Oenema A, Daha TJ, Richardus JH,. (2009). A Qualitative Exploration Of Reasons For Poor Hand Hygiene Among Hospital Workers: Lack Of Positive Role Models And Of Convincing Evidence That Hand Hygiene Prevents Cross-Infection. Infect Control Hosp Epidemiol. 30:415- 419. 